\title{
Effects of Urban Topography and Traffic Emissions of Ultrafine Particulate Matter, Reactive Nitrogen Species, and Ozone in Greater Los Angeles Area
}

Agam Mohan Singh Bhatia ( $\square$ agambhatia1812@gmail.com )

The Doon School https://orcid.org/0000-0003-1132-0926

\section{Article}

Keywords: Traffic-related Air Pollution, Ultrafine Particle Size and Concentration, Anthropogenic Particle Emissions

Posted Date: January 12th, 2021

DOl: https://doi.org/10.21203/rs.3.rs-139152/v1

License: (c) (1) This work is licensed under a Creative Commons Attribution 4.0 International License.

Read Full License 


\title{
Effects of Urban Topography and Traffic Emissions on Ultrafine Particulate Matter, Reactive Nitrogen Species, and Ozone in Greater Los Angeles Area
}

\author{
Agam Mohan Singh Bhatia
}

\section{Introduction}

Traffic-related air pollution (TRAP) is a major source of pollutant exposure in urban areas. ${ }^{1}$ TRAP has direct links to a wide range of adverse human health effects ${ }^{2}$ including exacerbation of asthma symptoms, ${ }^{3}$ diminished lung function, ${ }^{2,3}$ an increased risk of heart disease, ${ }^{4}$ adverse birth outcomes involving preterm births and low birth rates which give rise to long-term neurological problems, ${ }^{5}$ and childhood cancer. ${ }^{4,5}$ Ultrafine particles $($ UFPs; $<0.1 \mu \mathrm{m})$ have several more malignant health implications due to the ability of smaller particles to penetrate deeper into the lungs and potentially enter the bloodstream. ${ }^{6}$ UFPs have been proven to affect animal life. ${ }^{7}$ These particles have also harmed marine life by causing severe brain damage in fish, thereby resulting in ripple effects on the larger ecosystem. ${ }^{7}$ Reactive nitrogen species (RNS), while a contributor to particle concentrations and having significant influence over both ozone and UFP budgets, cause additional damaging environmental effects including severe algae blooms and mass fish kills. ${ }^{8}$ RNS have led to the formation of a "global nitrogen cascade," multiplying effects that link several ecosystems to cause terrestrial and coastal eutrophication, freshwater pollution, and biodiversity loss. ${ }^{9}$ The chemical reactivity of RNS is strongly influenced by the inversion of the surface layer and photochemical factors, indicating that dominant day and night chemistry will greatly influence the concentration and composition of these pollutants in any given area. ${ }^{10}$ Ozone and $\mathrm{NO}_{\mathrm{x}}$ are also directly related to each other (Figure 1). RNS and ozone are major reactants contributing to photochemical smog generation and degradation of air quality. ${ }^{11}$ Ground level ozone is also widely recognized as the most damaging air pollutant to vegetation due to its phytotoxicity and prevalence at high concentrations over rural/agricultural regions. ${ }^{12}$ With population growth and increased traffic in urban areas like Los Angeles, California, ${ }^{13}$ these pollutants and their subsequent health effects on humans, in addition to impacting economic growth, economic welfare, ${ }^{14}$ clean air, ${ }^{15}$ crop yield,${ }^{16}$ are likely to become more pervasive, resulting in severe environmental and economic costs of up to hundreds of billions of dollars. ${ }^{17}$ Additionally, with rising manufacturing rates, the release of particulate emissions in the atmosphere has been predicted to increase by around $20 \%$ by $2022,{ }^{18}$ raising concerns regarding the emissions of vehicles as the transport and size distribution of UFPs based on engine type in urban areas at present is not well understood. ${ }^{19,20}$ 


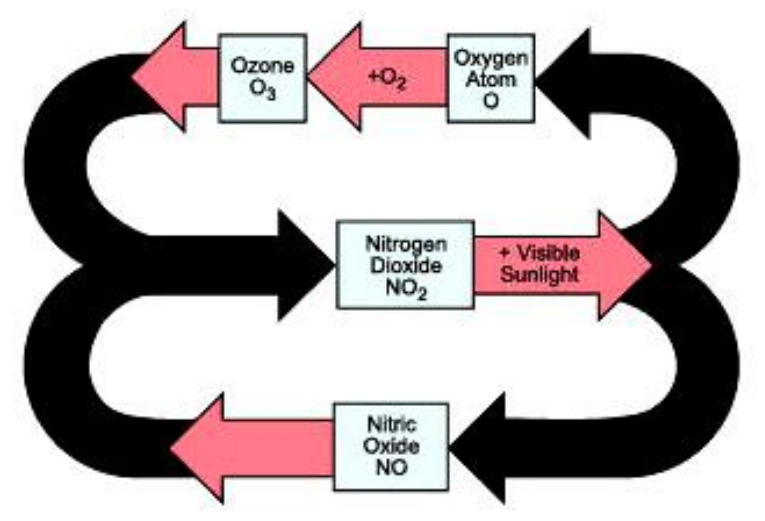

Figure 1. Ozone production from NOx pollutants: Oxygen atoms freed from nitrogen dioxide by the action of sunlight attack oxygen molecules to make ozone. Nitrogen oxide can combine with ozone to reform nitrogen dioxide, and the cycle repeats. (Image courtesy: National Institute of Environmental Health Sciences) $)^{21}$

High in-use passenger vehicles have been shown to produce significant amounts of $\mathrm{NO}_{\mathrm{x}}\left(\mathrm{NO}_{\mathrm{x}}=\mathrm{NO}_{2} \bullet+\right.$ NO•). ${ }^{22}$ The Clean Air Acts (1990) have regulated the amount of $\mathrm{NO}_{\mathrm{x}}$ produced by vehicles, prompting the use of catalytic converters to reduce $\mathrm{NO}_{x}$ to $\mathrm{N}_{2} \cdot{ }^{23}$ However, the converters often over-reduce to $\mathrm{NH}_{3}$ which has contributed to a high rise in the nitrogen budget, instead of a decline. ${ }^{24,25}$ Ammonia formation through this method also increases particle nucleation by several orders of magnitude. ${ }^{26}$ Reduction of $\mathrm{NO}_{\mathrm{x}}$ emissions from both two- and three-way catalytic converters in vehicles have been shown to increase $\mathrm{NH}_{\mathrm{x}}\left(=\mathrm{NH}_{3}+\mathrm{NH}_{4}{ }^{+}\right)$emissions by approximately $15 \%$ in the atmosphere..$^{27,28}$

Using Stable isotopes of Nitrogen $\left({ }^{15} \mathrm{~N},{ }^{14} \mathrm{~N}\right)$ as a tool to trace original sources of nitrogen pollutants through ratios ${ }^{15} \mathrm{~N} /{ }^{14} \mathrm{~N}$ sample compared directly to the international isotopic standard for nitrogen (atmospheric air) gives a number in a unit of per mil (\%o) $\left(\delta^{15} \mathrm{~N}\right.$ : \%o versus atmospheric $\mathrm{N}_{2}=\left(\left({ }^{15} \mathrm{~N} /{ }^{14} \mathrm{~N}_{\text {sample }} \div\left({ }^{15} \mathrm{~N} /{ }^{14} \mathrm{~N}_{\mathrm{AIR}}\right)-1\right) \times 1000\right.$ and $\delta^{18} \mathrm{O}$ : $\%$ versus Vienna Standard Mean Ocean Water $\left.=\left(\left({ }^{18} \mathrm{O} / /^{16} \mathrm{O}_{\text {sample }}\right) \div\left({ }^{18} \mathrm{O} /{ }^{16} \mathrm{O}_{\mathrm{VSMOw}}\right)-1\right) \times 1000\right) .{ }^{24,29,30,31,32,33,34,35}$ The partitioning of $\mathrm{NH}_{\mathrm{x}}$ between the gas, solid, and aqueous phases is driven by thermodynamic equilibrium that depends on the relative humidity, temperature, and particle chemical composition, making the separation of each phase(speciation) difficult. ${ }^{36}$ Isotopic analysis for source tracing has shown great promise in terms of requisite time resolution, quantitative collections of concentration and no fractionation upon collection for collection of $\mathrm{NH}_{\mathrm{x}(\mathrm{g})}$ and $\mathrm{pNH}_{4}{ }^{+}$with a reproducibility of $\leq 1.5 \%$ for application in multiple field environments. ${ }^{29}$ Specifically, high efficiency 
makes isotope analysis a suitable method for this study and allows for both spatial and temporal differences in isotopic ratios to be investigated using a single field-verified method that can capture $\mathrm{NO}_{\mathrm{x}}$ in solution. ${ }^{24}$

Organizations like the EPA in the United States have previously enacted regulations (Clean Air Acts 1990) in place to address pollutants such as $\mathrm{NO}_{\mathrm{x}} \mathrm{PM}_{2.5}, \mathrm{PM}_{10}$, and more but more focus is needed towards regulating anthropogenic UFP emissions. ${ }^{11}$ Of the regulations in place, few have been shown to have a discernible effect on UFP concentrations in Los Angeles, ${ }^{37,38,39}$ and none of them put any sort of limit on anthropogenic UFP emissions. ${ }^{40}$ Moreover, while the Clean Air Acts (1990) have reduced anthropogenic emissions of $\mathrm{SO}_{2}$ and $\mathrm{NO}_{\mathrm{x}}$ from fossil-fuel combustion sources, $\mathrm{NH}_{3}$ is yet to be regulated and has shown to be underestimated in many regions. ${ }^{31,41,42}$ With reports of $\mathrm{NH}_{3}$ emissions increasing as much as $6 \mathrm{x}$ in precipitation, this is a cause for concern. ${ }^{42}$

Various studies have attempted to qualitatively characterize both the chemical and physical particulate profiles of vehicular emissions in urban environments as well as monitoring $\mathrm{NO}_{\mathrm{x}}\left(\mathrm{NO}_{\mathrm{x}}=\mathrm{NO}_{2} \bullet+\mathrm{NO} \bullet\right)$ and $\mathrm{NH}_{\mathrm{x}}\left(\mathrm{NH}_{4}^{+}+\right.$ $\left.\mathrm{NH}_{3}\right) .^{43,44,45,46,47}$ However, such studies have failed to quantitatively explain concentrations and size distributions of these atmospheric UFP emissions by vehicle type and by their surrounding environments, specifically with regards to building architecture and morphology. UFP concentrations are higher in areas that have valleys, as pollutants trapped by geological topography, ${ }^{43}$ but few studies have attempted to test whether a similar relationship holds true with urban topography (e.g. tall, clustered buildings (>250 m)) in urban areas. A building height of $300 \mathrm{~m}$ classifies as a 'supertall' building which makes the height of a tall building $\sim 250 \mathrm{~m},{ }^{48}$ which is the definition that will be used in this proposal. UFP concentrations have been hypothesized to change with the time of day at which they are sampled, as the dispersion of these pollutants is related to the transport and mixing of air masses that are conditioned by the dynamic behavior of the surface layer with asymmetric forcing. ${ }^{49}$ Studying UFPs will improve the understanding of chemical reactivity and transportation in varied surrounding environments, which will be crucial for implementing specific policies for specific roads and local areas. Collecting UFPs on the ground will provide a direct comparison to study roadway emissions on short time scales. For appropriate analysis, this study aims to account for traffic in these sites through monitoring vehicle type. To account for air transportation, this study aims to use HYSPLIT modelling and keep track of forest fire locations to see any impact on the sampled particles in an urban environment. ${ }^{50}$ Furthermore, it aims to quantitatively depict the relationships between UFP concentrations, vehicle type, surrounding environment, and time of day. The hypothesis of this proposal is that UFP concentrations during the day will be lower for most sampling sites than concentrations sampled at sunset due to limited dispersion capacity combined with a smaller inversion layer 
as there is warmth near the surface versus the upper atmosphere, which is warmed by sunlight. The surrounding environment is also likely to play a role in surface-level micrometeorology by affecting temperature and wind speed and that highly condensed areas are likely to have higher UFP concentrations due to this inversion layer and their

unique topography. ${ }^{43}$ This means that areas with higher, taller buildings are likely to exhibit different levels of particulate counts. This research will have a great influence on environmental urban policies regarding UFP regulations as well as indicating whether urban topography has significant impact on major pollutants.

This study aims to further research in atmospheric and environmental sciences and influence decisions made regarding urban climate policy by furthering the understanding of UFP size and concentrations. It will lead to a better understanding of dangerous particles and act as a basis for future studies that aim to further understand or mitigate anthropogenic ultrafine particle emissions. This can help policymakers design and implement better, more effective policies that aim to reduce traffic-related air pollution exposure in urban areas.

The lack of regulations addressing UFP and $\mathrm{NH}_{\mathrm{x}}$ concentrations in the environment requires an understanding of the factors that affect it and introduces a gap in knowledge that has yet to be resolved. By monitoring concentrations and size distributions of UFPs, the effects of vehicular traffic composition and urban topography on UFP concentrations and reactive nitrogen species will become clearer.

\section{Method}

\section{1- Field Sampling in the Greater Los Angeles Area}

Los Angeles, in particular, has shown increases in population, land redevelopment, traffic congestion, and urban infrastructure in recent years, all of which are factors that have been the topic of interest for greater UFP depositions and increased ozone concentrations. ${ }^{8,9}$ Seven sampling site of approximately the same distance have been chosen in Los Angeles, California. These sites have been carefully chosen to have varying geographical features (from urban green space to rural valleys), vehicular traffic composition (this considers $>60 \%$ of each vehicle type (diesel or commercial engine) to be vehicle heavy roads), and building architecture (340-100 m) (Figure 2), which will allow for studying the effect of the surrounding environment on UFP concentrations and size distributions. A site will be sampled for a total of $12 \mathrm{~h}$ every day with two sampling time periods. The first time period will sample for a total of $6 \mathrm{~h}$ divided into $3 \mathrm{~h}$ before and after sunrise. The second time period will follow the same pattern but for sunset. The timings for sunrise and sunset will vary daily and Google Weather will be used to find out this time, after which 
samples will be taken accordingly. These measurements will be taken over a span of three summer months (JuneAugust). Since traveling along seven different locations everyday will not allow for efficient sampling of concentrations and size distributions for an appropriate amount of time, a single site will be sampled every day at the time periods aforementioned. The site to be sampled once a week will be chosen based on a random number generator daily. This method is suitable because it minimizes the possibility of a certain site being sampled on the same day every week, which can lead to inaccurate measurements as vehicular traffic varies with the day of the week. ${ }^{51}$

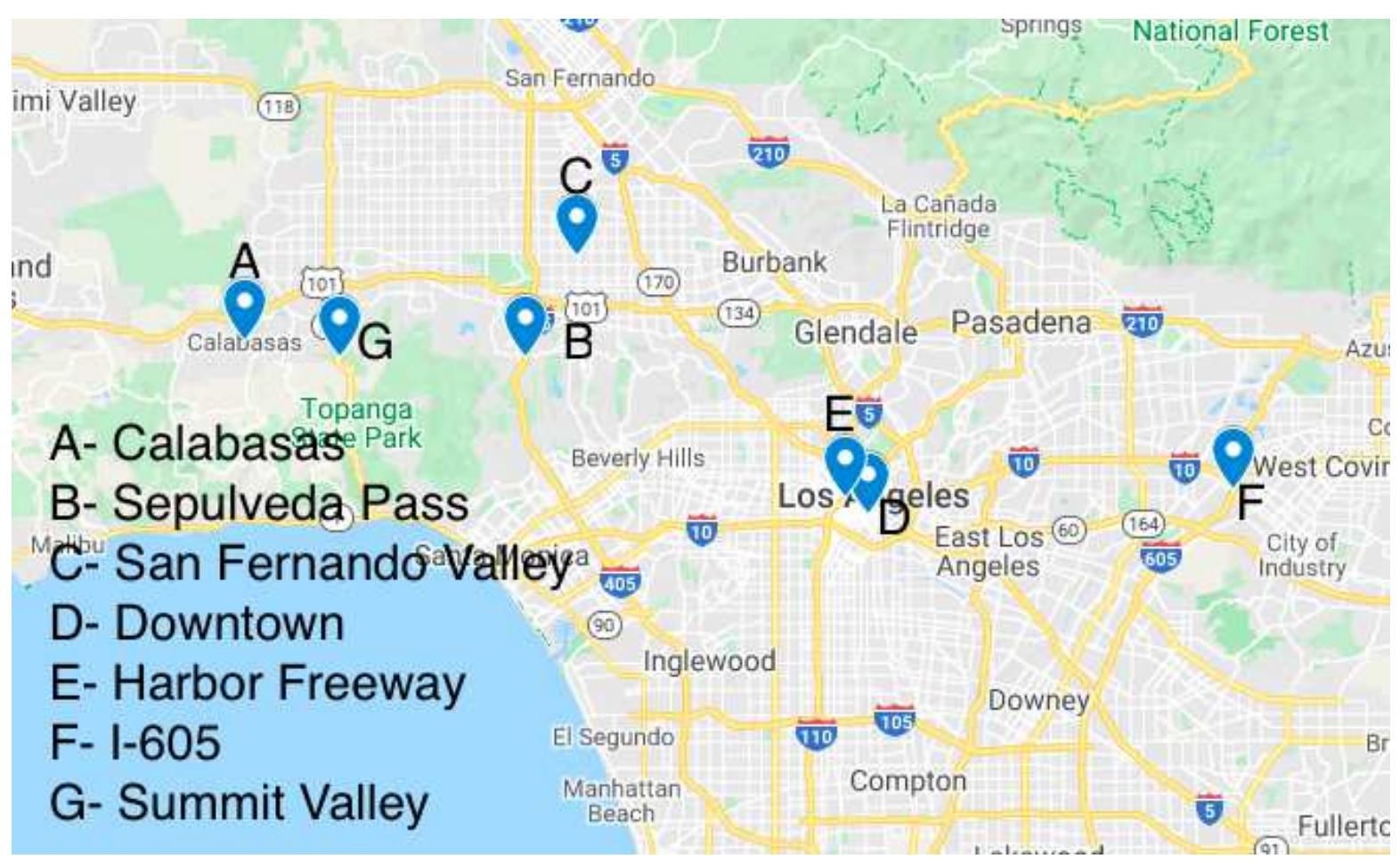

Figure 2. Map of Sampling Sites in wGreater Los Angeles Area. (A) Low-rise buildings, Low Total and Car Traffic, Valley Area; (B) Medium-rise buildings, High Car Traffic, Valley Area; (C) Low-rise buildings, High Truck Traffic, Valley Area; (D) High-rise buildings, High Car Traffic, Open Area; (E) High-rise buildings, High Truck Traffic, Open Area; (F) Low-rise buildings; Mix of both car and truck traffic; Open Area; (G) Low-rise buildings, Low Total and Truck Traffic; Valley Area ${ }^{52}$

\section{2- Pollutant Measurements and Collection}

A DiSCmini will be used to monitor size distributions and particle counts of particulate matter $(20-700 \mathrm{~nm})$ and the mean size of UFPs collected per second of analysis using a Pittsburgh ${ }^{\mathrm{TM}}$ Automotive 2.5 CFM Vacuum Pump. This pump will be used for the Chemcomb ${ }^{\mathrm{TM}}$ Speciation Cartridge (CCSC) mentioned below. Simultaneously, it also 
aims to monitor concentrations of ozone using an online analyzer. This study will report on $\delta^{15} \mathrm{~N}^{-\mathrm{NH}} \mathrm{x}$ precision using the denuder-filter pack combination comprising a filter configuration of a nylon filter and a downstream acidimpregnated cellulose filter which will collect volatilized $\mathrm{NH}_{4}{ }^{+}$from particulate species in ambient air samples. ${ }^{31}$ The method aforementioned characterizes $\delta^{15} \mathrm{~N}^{-\mathrm{NH}_{3}}$ spatiotemporal variabilities from vehicle emissions using a glass honeycomb denuder-filter pack sampling system. ${ }^{31}$ This involves a commercially available CCSC explained by Blum et al.(2020 under review). ${ }^{32}$ The filter pack is located at the end of this cartridge to collect the remaining particulate species. ${ }^{50}$ The denuder-filter combination is a well-established sampling technique that can effectively collect and speciate $\mathrm{NH}_{\mathrm{x}}$ and $\mathrm{pNH}_{4}{ }^{+}{ }^{53}$ For isotopic ratio analysis, this study will use the azide method to convert $\mathrm{NH}_{4}{ }^{+}$to nitrous oxide $\left(\mathrm{N}_{2} \mathrm{O}\right)$ to be run on an isotope ratio mass spectrometer (IRMS). ${ }^{35,31,54}$ These methods have been particularly useful where concentrations of samples have varied over a large range, because of increased sample volumes in a shorter time resolution. ${ }^{30}$

\section{3- Mobile Monitoring Station}

A van will serve as a mobile monitoring platform. This platform will have an array of online instruments to measure various air pollutants including bulk UFP size distribution (DiSCmini), ${ }^{43} \mathrm{NO}_{\mathrm{x}}$ concentrations(online $\mathrm{NO}_{\mathrm{x}}$ analyzer), ${ }^{29}$ and ozone concentrations (online analysis devices). ${ }^{55}$ Offline analysis on denuder-filter packs will be used to determine concentration of speciated $\mathrm{NH}_{\mathrm{x}}{ }^{31}$ An APEMANTM dash camera and a mounted rear camera will be used to later count and differentiate between surrounding vehicles to further understand the effect of engine type and urban architecture in high traveled traffic areas have on particle $\mathrm{NO}_{\mathrm{x}}$, ozone, and $\mathrm{NH}_{\mathrm{x}}$ concentrations as well as particle size, as demonstrated by Choi et al (2016). ${ }^{18}$ In all cases, the instruments used will be located on the passenger side of the vehicle near the roofline to get the best possible measurements and secured using a strap method as described in Ott et al (2008). ${ }^{56}$ This study will also employ the use of other calculations such as the aerial aspect ratio ( $\left.\mathrm{Ar}_{\text {area }}\right)$ (Eq.1) which estimate building morphology. This indicator specifically includes the area-weighted building height, the amount of open space, and the building footprint (total area surrounded by the exterior wall of a building or portion of a building, measured at the foundation). Utilizing Eq. 1 in conjunction with pollution data (particle counts, particle size, concentrations of ozone, $\mathrm{NO}_{\mathrm{x}}$, and $\mathrm{NHx}$ ) will allow for correlations to be drawn between urban topography and the aforementioned pollutants. 


$$
\begin{gathered}
A r_{\text {area }}=\frac{H_{\text {area }}}{W_{\text {street }}} \\
\text { where } \\
\mathrm{H}_{\text {arca }}=\text { building area weighted height }(\mathrm{m}) \text { and } \\
\mathrm{W}_{\text {strect }}=\text { street width }(\mathrm{m})
\end{gathered}
$$

\section{4- Possible Implications}

August enters peak biomass burning season for California, meaning there may be implications of source changes in pollutants and increased pollutant concentrations during this time that can be captured and monitored by this study. Wind directions, acreage, and locations of biomass burnings will be monitored and assessed using the Hybrid Single-Particle Lagrangian Integrated Trajectory model (HYSPLIT), which uses wind trajectory analysis to determine the origin of air masses and establish source-receptor relationships ${ }^{50}$ In conjunction with monitoring, wind directions, and knowledge of biomass burning sizes and locations, effects of biomass burnings on concentrations of $\mathrm{NO}_{\times}, \mathrm{NH}_{4}$, and UFPs can be correlated.

\section{Conclusion}

This proposal is unique in that it aims to study the role of surrounding geography and traffic type on several harmful pollutants. These factors have either been unaddressed or mentioned briefly in previous studies indicating a gap in knowledge that needs to be closed. ${ }^{46,57,58,59}$ Crucially, this proposal will delineate the concentrations of these pollutants, where they come from (RNS), and how they can be regulated in the near future. The use of a variety of sampling locations will allow for appropriate controls and analysis of relations between these pollutants and urban topography. Additionally, this will provide useful information in determining specific factors that affect their concentrations. Broadly, this proposal will further the fields of the environmental and atmospheric sciences by analyzing UFP and reactive nitrogen chemistry with respect to their sources and surroundings, both of which are crucial factors for obtaining a more complete understanding of these pollutants. This proposal has implications for urban planning, architecture, traffic management policies, and air pollution exposure of both pedestrians and vehicle 
occupants in urban and rural centers. More generally, this proposal will provide critical insights into how the surrounding environment and traffic type influence concentrations of UFPs and reactive nitrogen species, which will provide useful data for urban planners and traffic managers developing strategies to reduce street level pollutant concentrations. Additionally, this proposal will bring to attention the pervasive nature and perilous impacts of UFPs, issues that require immediate and unprecedented attention.

This proposal can pave the path for deepening our understanding of UFPs, reactive nitrogen species, and ozone by detailing the effects of traffic and urban topography. Particularly, the use of isotopic analysis for reactive nitrogen compounds can facilitate the collection of data with large spatial and temporal coverage. The analysis of pollutant concentrations by engine type will be an important step in reducing their detrimental impacts. This proposal's aim to study the effect of the surrounding environment on vehicular emissions will provide crucial insights into the role of topography and building morphology. In the context of rising anthropogenic emission levels and rapid population growth, this proposal can provide necessary, nuanced, and valuable analysis of a major source of urban pollutant exposure which has proven to show adverse impacts on both humans and the wider climate. 


\section{References}

(1) von Schneidemesser, E.; Steinmar, K.; Weatherhead, E. C.; Bonn, B.; Gerwig, H.; Quedenau, J. Air Pollution at Human Scales in an Urban Environment: Impact of Local Environment and Vehicles on Particle Number Concentrations. Sci. Total Environ. 2019, 688, 691-700. https://doi.org/10.1016/j.scitotenv.2019.06.309.

(2) Matz, C. J.; Egyed, M.; Hocking, R.; Seenundun, S.; Charman, N.; Edmonds, N. Human Health Effects of Traffic-Related Air Pollution (TRAP): A Scoping Review Protocol. Syst. Rev. 2019, 8 (1), 223. https://doi.org/10.1186/s13643-019-1106-5.

(3) Paulin, L.; Hansel, N. Particulate Air Pollution and Impaired Lung Function. F1000Research $2016,5$. https://doi.org/10.12688/f1000research.7108.1.

(4) Lee, B.-J.; Kim, B.; Lee, K. Air Pollution Exposure and Cardiovascular Disease. Toxicol. Res. 2014, 30 (2), 71-75. https://doi.org/10.5487/TR.2014.30.2.071.

(5) Guo, L.-Q.; Chen, Y.; Mi, B.-B.; Dang, S.-N.; Zhao, D.-D.; Liu, R.; Wang, H.-L.; Yan, H. Ambient Air Pollution and Adverse Birth Outcomes: A Systematic Review and Meta-Analysis. J. Zhejiang Univ. Sci. B 2019, 20 (3), 238-252. https://doi.org/10.1631/jzus.B1800122.

(6) Schraufnagel, D. E. The Health Effects of Ultrafine Particles. Exp. Mol. Med. 2020, 52 (3), $311-317$. https://doi.org/10.1038/s12276-020-0403-3.

(7) Fortoul, T. I.; Rodriguez-Lara, V.; Gonzalez-Villalva, A.; Rojas-Lemus, M.; Colin-Barenque, L.; BizarroNevares, P.; García-Peláez, I.; Ustarroz-Cano, M.; López-Zepeda, S.; Cervantes-Yépez, S.; López-Valdez, N.; Meléndez-García, N.; Espinosa-Zurutuza, M.; Cano-Rodríguez, G. C.-G. and M. C. Health Effects of Metals in Particulate Matter. Curr. Air Qual. Issues 2015. https://doi.org/10.5772/59749.

(8) Fiore, A. M.; Jacob, D. J.; Field, B. D.; Streets, D. G.; Fernandes, S. D.; Jang, C. Linking Ozone Pollution and Climate Change: The Case for Controlling Methane: LINKING OZONE POLLUTION AND CLIMATE CHANGE. Geophys. Res. Lett. 2002, 29 (19), 25-1-25-4. https://doi.org/10.1029/2002GL015601.

(9) Erisman, J. W.; Galloway, J. N.; Seitzinger, S.; Bleeker, A.; Dise, N. B.; Petrescu, A. M. R.; Leach, A. M.; de Vries, W. Consequences of Human Modification of the Global Nitrogen Cycle. Philos. Trans. R. Soc. B Biol. Sci. 2013, 368 (1621), 20130116. https://doi.org/10.1098/rstb.2013.0116.

(10) Miao, Y.; Li, J.; Miao, S.; Che, H.; Wang, Y.; Zhang, X.; Zhu, R.; Liu, S. Interaction Between Planetary Boundary Layer and PM2.5 Pollution in Megacities in China: A Review. Curr. Pollut. Rep. 2019, 5 (4), 261-271. https://doi.org/10.1007/s40726-019-00124-5.

(11) Seinfeld, J. H.; Pandis, S. N. Atmospheric Chemistry and Physics: From Air Pollution to Climate Change; John Wiley \& Sons, 2016.

(12) Emberson, L. D.; Pleijel, H.; Ainsworth, E. A.; van den Berg, M.; Ren, W.; Osborne, S.; Mills, G.; Pandey, D.; Dentener, F.; Büker, P.; Ewert, F.; Koeble, R.; Van Dingenen, R. Ozone Effects on Crops and Consideration in Crop Models. Eur. J. Agron. 2018, 100, 19-34. https://doi.org/10.1016/j.eja.2018.06.002.

(13) Houston, D.; Wu, J.; Ong, P.; Winer, A. Structural Disparities of Urban Traffic in Southern California: Implications for Vehicle-Related Air Pollution Exposure in Minority and High-Poverty Neighborhoods. $J$. Urban Aff. 2004, 26 (5), 565-592. https://doi.org/10.1111/j.0735-2166.2004.00215.x.

(14) Bloom, D. E.; Kuhn, M.; Prettner, K. Health and Economic Growth. 2018, 28.

(15) De Marco, A.; Proietti, C.; Anav, A.; Ciancarella, L.; D’Elia, I.; Fares, S.; Fornasier, M. F.; Fusaro, L.; Gualtieri, M.; Manes, F.; Marchetto, A.; Mircea, M.; Paoletti, E.; Piersanti, A.; Rogora, M.; Salvati, L.; Salvatori, E.; Screpanti, A.; Vialetto, G.; Vitale, M.; Leonardi, C. Impacts of Air Pollution on Human and Ecosystem Health, and Implications for the National Emission Ceilings Directive: Insights from Italy. Environ. Int. 2019, 125, 320-333. https://doi.org/10.1016/j.envint.2019.01.064.

(16) Tuomisto, H. L.; Scheelbeek, P. F. D.; Chalabi, Z.; Green, R.; Smith, R. D.; Haines, A.; Dangour, A. D. Effects of Environmental Change on Agriculture, Nutrition and Health: A Framework with a Focus on Fruits and Vegetables. Wellcome Open Res. 2017, 2. https://doi.org/10.12688/wellcomeopenres.11190.2.

(17) Avila, A. M.; Mezić, I. Data-Driven Analysis and Forecasting of Highway Traffic Dynamics. Nat. Commun. 2020, 11 (1), 2090. https://doi.org/10.1038/s41467-020-15582-5.

(18) Winkler, S. L.; Anderson, J. E.; Garza, L.; Ruona, W. C.; Vogt, R.; Wallington, T. J. Vehicle Criteria Pollutant (PM, NO x , CO, HCs) Emissions: How Low Should We Go? Npj Clim. Atmospheric Sci. 2018, 1 (1), 1-5. https://doi.org/10.1038/s41612-018-0037-5. 
(19) Baldauf, R. W.; Devlin, R. B.; Gehr, P.; Giannelli, R.; Hassett-Sipple, B.; Jung, H.; Martini, G.; McDonald, J.; Sacks, J. D.; Walker, K. Ultrafine Particle Metrics and Research Considerations: Review of the 2015 UFP Workshop. Int. J. Environ. Res. Public. Health 2016, 13 (11). https://doi.org/10.3390/ijerph13111054.

(20) Kumar, P.; Morawska, L.; Birmili, W.; Paasonen, P.; Hu, M.; Kulmala, M.; Harrison, R. M.; Norford, L.; Britter, R. Ultrafine Particles in Cities. Environ. Int. 2014, 66, 1-10.

https://doi.org/10.1016/j.envint.2014.01.013.

(21) Beckett, W. S. Ozone, Air Pollution, and Respiratory Health. Yale J. Biol. Med. 1991, 64 (2), 167-175.

(22) Knop, V.; Nicolle, A.; Colin, O. Modelling and Speciation of Nitrogen Oxides in Engines. Proc. Combust. Inst. 2013, 34 (1), 667-675. https://doi.org/10.1016/j.proci.2012.06.082.

(23) Warner, J. X.; Dickerson, R. R.; Wei, Z.; Strow, L. L.; Wang, Y.; Liang, Q. Increased Atmospheric Ammonia over the World's Major Agricultural Areas Detected from Space. Geophys. Res. Lett. 2017, 44 (6), 2875-2884. https://doi.org/10.1002/2016GL072305.

(24) Walters, W. W.; Song, L.; Chai, J.; Fang, Y.; Colombi, N.; Hastings, M. G. Constraining Ammonia Emissions in Vehicle Plumes Utilizing Nitrogen Stable Isotopes; preprint; Gases/Field Measurements/Troposphere/Chemistry (chemical composition and reactions), 2020. https://doi.org/10.5194/acp-2020-188.

(25) Rathod, N.; Panage, R.; Rathod, W. S. Design and Performance Analysis of a Three Way Catalytic Converter. 2018, 6.

(26) Suarez-Bertoa, R.; Mendoza-Villafuerte, P.; Riccobono, F.; Vojtisek, M.; Pechout, M.; Perujo, A.; Astorga, C. On-Road Measurement of NH3 Emissions from Gasoline and Diesel Passenger Cars during Real World Driving Conditions. Atmos. Environ. 2017, 166, 488-497. https://doi.org/10.1016/j.atmosenv.2017.07.056.

(27) Taylor, K. C. Automobile Catalytic Converters. In Studies in Surface Science and Catalysis; Crucq, A., Frennet, A., Eds.; Catalysis and Automotive Pollution Control; Elsevier, 1987; Vol. 30, pp 97-116. https://doi.org/10.1016/S0167-2991(09)60416-X.

(28) Suarez-Bertoa, R.; Zardini, A. A.; Astorga, C. Ammonia Exhaust Emissions from Spark Ignition Vehicles over the New European Driving Cycle. Atmos. Environ. 2014, 97, 43-53. https://doi.org/10.1016/j.atmosenv.2014.07.050.

(29) Wojtal, P. K.; Miller, D. J.; O’Connor, M.; Clark, S. C.; Hastings, M. G. Automated, High-Resolution Mobile Collection System for the Nitrogen Isotopic Analysis of NOx. JoVE J. Vis. Exp. 2016, No. 118, e54962. https://doi.org/10.3791/54962.

(30) Hastings, M. G.; Casciotti, K. L.; Elliott, E. M. Stable Isotopes as Tracers of Anthropogenic Nitrogen Sources, Deposition, and Impacts. Elements 2013, 9 (5), 339-344. https://doi.org/10.2113/gselements.9.5.339.

(31) Walters, W. W.; Hastings, M. G. Collection of Ammonia for High Time-Resolved Nitrogen Isotopic Characterization Utilizing an Acid-Coated Honeycomb Denuder. Anal. Chem. 2018, 90 (13), 8051-8057. https://doi.org/10.1021/acs.analchem.8b01007.

(32) Blum, D. E.; Walters, W. W.; Hastings, M. G. Development of Highly-Speciated NOy Collection Method for Nitrogen and Oxygen Stable Isotope Analysis $(\Delta 15 \mathrm{~N}, \Delta 17 \mathrm{O}, \Delta 18 \mathrm{O})$. AGU Fall Meet. Abstr. 2018, 21.

(33) Martin, T. S.; Primeau, F.; Casciotti, K. L. Assessing Marine Nitrogen Cycle Rates and Process Sensitivities With a Global 3-D Inverse Model. Glob. Biogeochem. Cycles 2019, 33 (8), 1026-1047. https://doi.org/10.1029/2018GB006088.

(34) Riha, K. M.; Michalski, G.; Gallo, E. L.; Lohse, K. A.; Brooks, P. D.; Meixner, T. High Atmospheric Nitrate Inputs and Nitrogen Turnover in Semi-Arid Urban Catchments. Ecosystems 2014, 17 (8), 1309-1325. https://doi.org/10.1007/s10021-014-9797-x.

(35) Sigman, D. M.; Casciotti, K. L.; Andreani, M.; Barford, C.; Galanter, M.; Böhlke, J. K. A Bacterial Method for the Nitrogen Isotopic Analysis of Nitrate in Seawater and Freshwater. Anal. Chem. 2001, 73 (17), 41454153. https://doi.org/10.1021/ac010088e.

(36) Sun, K.; Tao, L.; Miller, D. J.; Pan, D.; Golston, L. M.; Zondlo, M. A.; Griffin, R. J.; Wallace, H. W.; Leong, Y. J.; Yang, M. M.; Zhang, Y.; Mauzerall, D. L.; Zhu, T. Vehicle Emissions as an Important Urban Ammonia Source in the United States and China. Environ. Sci. Technol. 2017, 51 (4), 2472-2481. https://doi.org/10.1021/acs.est.6b02805.

(37) Diaz, E.; Mariën, K.; Manahan, L.; Fox, J. Summary of Health Research on Ultrafine Particles. 2019, 27.

(38) The Impact of the Clean Air Act - The Journal of Pediatrics https://www.jpeds.com/article/S00223476(12)00752-4/abstract (accessed Aug 29, 2020).

(39) Greenbaum, D. S. The Clean Air Act: Substantial Success and the Challenges Ahead. Ann. Am. Thorac. Soc. 2017, 15 (3), 296-297. https://doi.org/10.1513/AnnalsATS.201710-763PS. 
(40) Development, O. of R. \&. An Overview of Ultrafine Particles in Ambient Air https://cfpub.epa.gov/si/si_public_record_report.cfm?Lab=NERL\&dirEntryId=241266 (accessed Aug 21, 2020).

(41) Global modeling of nitrate and ammonium: Interaction of aerosols and tropospheric chemistry - Feng - 2007 - Journal of Geophysical Research: Atmospheres - Wiley Online Library https://agupubs.onlinelibrary.wiley.com/doi/full/10.1029/2005JD006404 (accessed Sep 10, 2020).

(42) Joyce, E. E.; Walters, W. W.; Le Roy, E.; Clark, S. C.; Schiebel, H.; Hastings, M. G. Highly Concentrated Atmospheric Inorganic Nitrogen Deposition in an Urban, Coastal Region in the US. Environ. Res. Commun. 2020, 2 (8), 081001. https://doi.org/10.1088/2515-7620/aba637.

(43) Choi, W.; Ranasinghe, D.; Bunavage, K.; DeShazo, J. R.; Wu, L.; Seguel, R.; Winer, A. M.; Paulson, S. E. The Effects of the Built Environment, Traffic Patterns, and Micrometeorology on Street Level Ultrafine Particle Concentrations at a Block Scale: Results from Multiple Urban Sites. Sci. Total Environ. 2016, 553, 474-485. https://doi.org/10.1016/j.scitotenv.2016.02.083.

(44) Hughes, L. S.; Cass, G. R.; Gone, J.; Ames, M.; Olmez, I. Physical and Chemical Characterization of Atmospheric Ultrafine Particles in the Los Angeles Area. Environ. Sci. Technol. 1998, 32 (9), 1153-1161. https://doi.org/10.1021/es970280r.

(45) Paulson, S. Identifying Urban Designs and Traffic Management Strategies for Southern California That Reduce Air Pollution Exposure. 131.

(46) Kwon, H.-S.; Ryu, M. H.; Carlsten, C. Ultrafine Particles: Unique Physicochemical Properties Relevant to Health and Disease. Exp. Mol. Med. 2020, 52 (3), 318-328. https://doi.org/10.1038/s12276-020-0405-1.

(47) Aggarwal, S.; Jain, R.; Marshall, J. D. Real-Time Prediction of Size-Resolved Ultrafine Particulate Matter on Freeways. Environ. Sci. Technol. 2012, 46 (4), 2234-2241. https://doi.org/10.1021/es203290p.

(48) Tall building https://www.designingbuildings.co.uk/wiki/Tall_building (accessed Sep 9, 2020).

(49) Chapter 7 Atmospheric Stability and Pollutant Dispersion. In Developments in Atmospheric Science; Camuffo, D., Ed.; Microclimate for Cultural Heritage; Elsevier, 1998; Vol. 23, pp 195-234. https://doi.org/10.1016/S0167-5117(98)80010-4.

(50) Stein, A. F.; Draxler, R. R.; Rolph, G. D.; Stunder, B. J. B.; Cohen, M. D.; Ngan, F. NOAA’s HYSPLIT Atmospheric Transport and Dispersion Modeling System. Bull. Am. Meteorol. Soc. 2015, 96 (12), 20592077. https://doi.org/10.1175/BAMS-D-14-00110.1.

(51) Downs, A. Traffic: Why It's Getting Worse, What Government Can Do. Brookings, 2004.

(52) Los Angeles and Southern California Traffic https://abc7.com/traffic/ (accessed Sep 9, 2020).

(53) Yu, X.-Y.; Lee, T.; Ayres, B.; Kreidenweis, S. M.; Jr, J. L. C.; Malm, W. Particulate Nitrate Measurement Using Nylon Filters. J. Air Waste Manag. Assoc. 2005, 55 (8), 1100-1110. https://doi.org/10.1080/10473289.2005.10464721.

(54) Blum, E., Danielle; Walters, W. W.; Hastings, M. G. Supplemental to "Speciated Collection of Nitric Acid and Fine Particulate Nitrate for Nitrogen and Oxygen Stable Isotope Determination".

(55) The ozone monitoring instrument - IEEE Journals \& Magazine https://ieeexplore.iee.org/document/1624590 (accessed Aug 26, 2020).

(56) Ott, W.; Klepeis, N.; Switzer, P. Air Change Rates of Motor Vehicles and In-Vehicle Pollutant Concentrations from Secondhand Smoke. J. Expo. Sci. Environ. Epidemiol. 2008, 18 (3), 312-325. https://doi.org/10.1038/sj.jes.7500601.

(57) Campagnolo, D.; Cattaneo, A.; Corbella, L.; Borghi, F.; Del Buono, L.; Rovelli, S.; Spinazzé, A.; Cavallo, D. M. In-Vehicle Airborne Fine and Ultra-Fine Particulate Matter Exposure: The Impact of Leading Vehicle Emissions. Environ. Int. 2019, 123, 407-416. https://doi.org/10.1016/j.envint.2018.12.020.

(58) Exhaust Particulate Matter https://dieselnet.com/tech/dpm.php (accessed Sep 10, 2020).

(59) Bhardawaj, A.; Habib, G.; Kumar, A.; Singh, S.; Nema, A. K. A Review of Ultrafine Particle-Related Pollution during Vehicular Motion, Health Effects and Control. J. Environ. Sci. Public Health 2017, 01 (04), 268-288. https://doi.org/10.26502/jesph.96120024. 


\section{Figures}

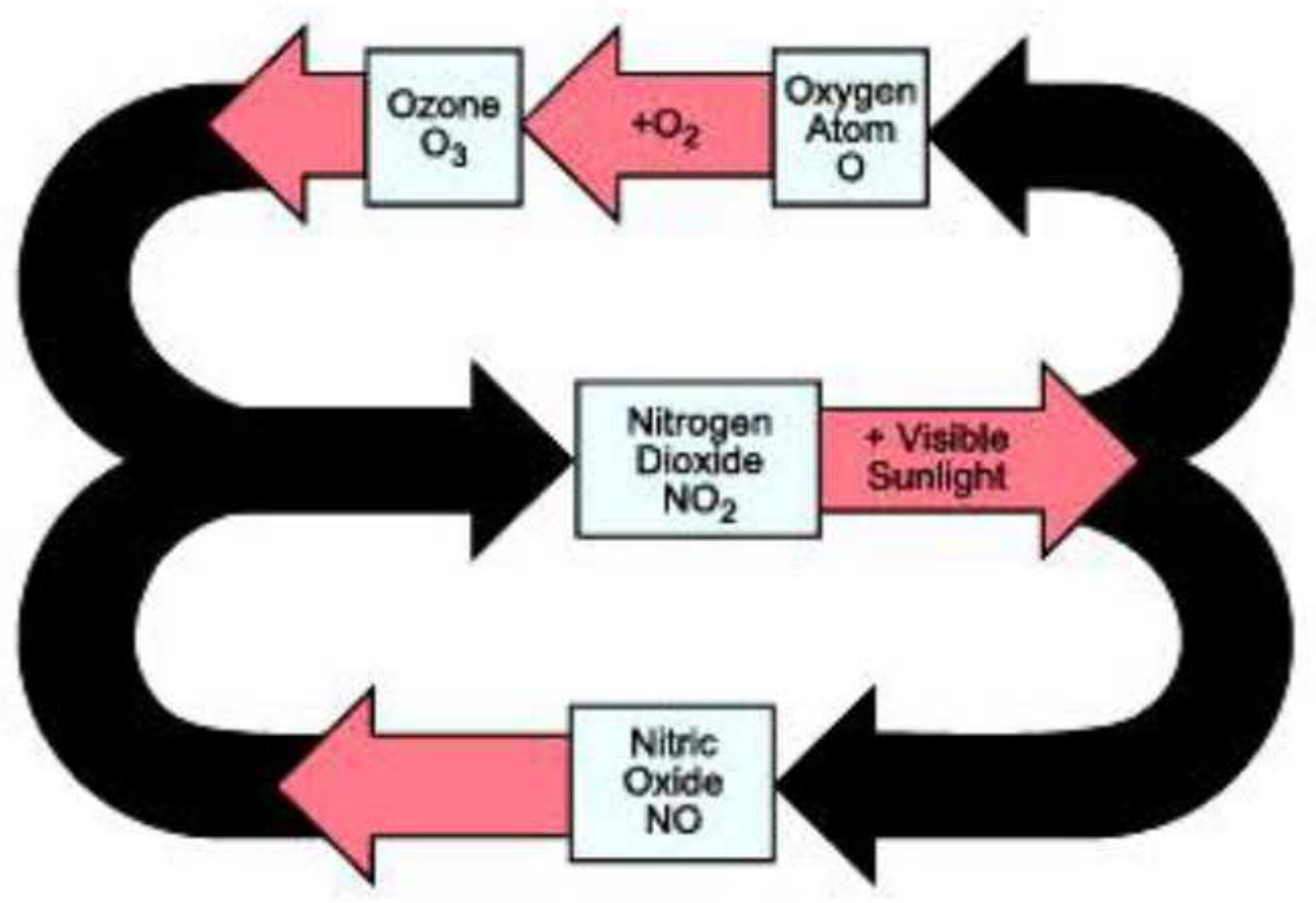

Figure 1

Ozone production from NOx pollutants: Oxygen atoms freed from nitrogen dioxide by the action of sunlight attack oxygen molecules to make ozone. Nitrogen oxide can combine with ozone to reform nitrogen dioxide, and the cycle repeats. (Image courtesy: National Institute of Environmental Health Sciences) 21 
imi Valley

(118)

nd

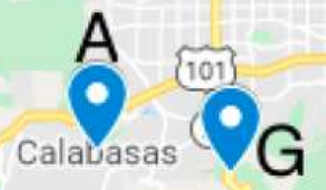

Topanga

A- Calabasase Park

B- Sepulveda Pass

"C-San Fernando Valleya

D- Downtown

E- Harbor Freeway

F- I-605

G- Summit Valley
San Fernando

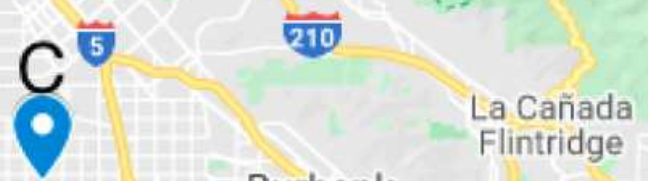

springș National Forest
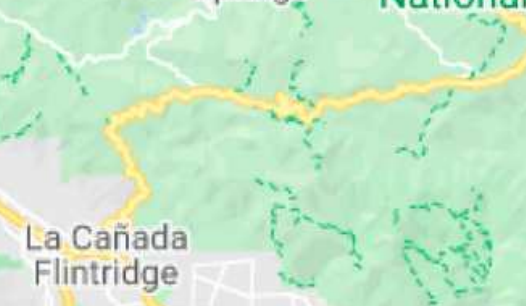

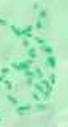

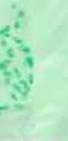

Burbank

Flintridge

(134) Glendale Pasadena 210
B

\section{(170)}

Beverly Hills

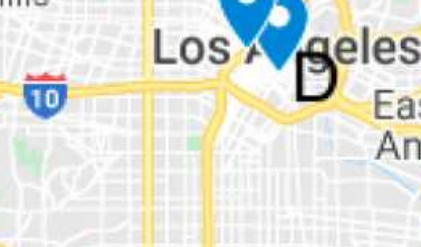

East Los (60)
Angeles

(90)

Inglewood
(10

Manhattan

Beach
Downey

Compton
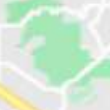